\title{
EGFR T790M Antagonist BPI-15086
}

National Cancer Institute

\section{Source}

National Cancer Institute. EGFR T790M Antagonist BPI-15086. NCI Thesaurus. Code C131909.

An orally available inhibitor of the epidermal growth factor receptor (EGFR) mutant form T790M, with potential antineoplastic activity. EGFR T790M antagonist BPI-15086 specifically binds to and inhibits EGFR T790M, a secondarily acquired resistance mutation, which prevents EGFR-mediated signaling and leads to cell death in EGFR T 790Mexpressing tumor cells. EGFR, a receptor tyrosine kinase that is mutated in many tumor cell types, plays a key role in tumor cell proliferation and tumor vascularization. 